\title{
THE INTERNATIONALIZATION OF THE INTERNATIONAL CONTRACT ACCORDING TO INTERNATIONAL THEORIES AND CONVENTIONS
}

\author{
Emad Mohammed Al-Amaren \\ Yarmouk University, Jordan \\ Email: amareenroma1993@gmail.com
}

\begin{abstract}
The contract generally means the consent of two wills to make a particular legal effect of giving or doing work or abstaining from work in return for material or inkind compensation. As for the commercial nature of the contract, in the Jordanian civil law, the contract is considered commercial if it is included in the business stipulated in Article 6 of the Jordanian Trade Law. A contract is commercial if its subject matter is one of the acts provided for in article 6 of the Trade Law, as is the case with the purchase of movables for the purpose of selling them, and the agency commission and brokerage. On the international level, the commercial character of the contract comes closest to the extent to which the contract relates to international trade as the export or import of goods that regulate the movement of goods across the borders of one State. After the good study of the subject, we find that there are a number of questions or problems that accompany the determination of the internationality of the contract, including the extant of adequacy of the personal internationality, in addition to, whether the introduction of the purely national relationship to the jurisdiction of the foreign country lead to the internationalization of the relationship. The study will deal with international standards of the contract in different international theories and conventions. I will discuss the legal and economic standard in section I, the mixed standard in section II and the standards of the internationality of the contract in accordance to international conventions, especially the Vienna Conventions, The Hague Convention, the Rome Convention and the International Convention on International Arbitration in Section III.
\end{abstract}

Keywords: contract, internationalization, the standard of the internationality of contract, internationality of personal and economic

\section{A. INTRODUCTION}

The Jordanian legislator defined the contract in article 87 of the Jordanian Civil Code by saying: "The contract is the relationship of the offer made by a contractor to the acceptance of the other and their concurrence in a manner that proves its effect on the contract and the obligation of each of them to the other" (Jordanian Civil Law, 1976). An international contract is defined as an agreement between two or more individuals of a private law that, by its legal and economic nature, exceeds the limits of an internal law system or is in the same circumstances with a person of internal

\begin{tabular}{l|ll}
428 & Yustisia Vol. 7 Number 3 (Sept.-Dec. 2018) $\quad$ The Internationalization Of The ...
\end{tabular}

C2018; This is an Open Acces Research distributed under the term of the Creative Commons Attribution Licencee (https://Creativecommons.org/licences/by/4.0), which permits unrestricted use, distribution, and reproduction in any medium, provided the original works is properly cited. 
public law or with international law persons who do not appear in the contract as an internal or international public authority. (Mohammad Saad Al-Din,2008:9)

Dr. Ahmed Al-Qusairi also defined the international contract as the contract whose main focus is related to different legal systems. Dr. Zorti Al-Tayeb defined the contract as the contract which is related to different legal systems, ie, more than a legal system and is related to international trade (Mohammad Saad AlDin,2008:16). The jurist Batifoul defined the international contract as the contract that includes a foreign element. The jurist Rabel said that the international contract is understood by the concept of the violator of the internal contract since the internal contract is connected to all its elements by one sovereignty and that is free from every foreign element. (Khalid Schuerb,2009:15)

It is important to identify the concept of an international contract and what distinguishes it from other contracts, as the definition of the international contract and the identification of what distinguishes it from similar contracts is an urgent necessity because of the special importance that the characteristics of these contracts have. These includes: The automatic exclusion of domestic law and resorting to the conversion of the legal rules governing international contracts, whether they are internal rules that are competent according to international law or substantive rules or, in other words, the determination of jurisdiction in the international contract. Reinforcing the views of the parties in determining the law applicable to the international contract pursuant to the principle of the power of the will, i.e., to respect the freedom of the parties to choose the law they wish, based on the principle that the contract is the law of the contracting parties, and this is contrary to the internal contract under which the internal law must be applied. It is permissible to include conditions in the international contract that are originally invalid in the internal contract, such as the requirement of payment in gold / the requirement of legal stability. The arbitration clause is considered as evidence of the internationality of a contract in the sense that there is an overlap between the internationality of the contract and the internationality of arbitration and that the arbitration clause is independent in the contract and is acceptable only in the international contract (Mohammad Saad Al-Din,2008:17).

\section{B. THE TYPES OF THE INTERNATIONALITY OF CONTRACT}

It should be noted that most of the jurisprudence, headed by the French jurist Mayer who said that there are two types of the internationality of the contract. They are absolute or objective internationality and relative personal internationality. In general, the relationship is international for the national judge if it contains a foreign element by which the judge has even partial contact with the foreign legal system (Akasha Abdel Aal,2007:80). 


\section{Personal Internationality}

The French jurist Mayer says about personal internationality:

"There is nothing wrong with the description of the internationality on the relationship based entirely within one territory when offering this relationship to a foreign judiciary, considering that the international character leaked to the relationship just because it is subject to the jurisdiction of a foreign state. (Akasha Abdel Aal,2007:80)

Therefore, Mayer's opinion can be described as that the personal internationality emerges in two cases; the first when the element changes in the relationship because of the judiciary that is considering the case, and the second is when the whole relationship is focused in the law of one state and the description" international" leaks into it just because it is subject to the judiciary of another state. (Akasha Abdel Aal,2007:80).

The internationality is also considered personal if the foreign status has touched on a legal element which differs because of the judge considering the issue as if the relationship touched the marriage of two Italians living in France (Sadiq: Hisham Ali,2007:85) Professor Mayer also pointed out that the relative internationality would also be if the elements of this relationship were based in one state while the dispute was brought before the jurisdiction of another state. Examples include a sale contract between two people residing in Jordan and being implemented in Jordan, but The dispute arose before the Lebanese judiciary. The internationality here is relative based on the fact that if this incident was presented to the Jordanian judiciary, it would be local or national since all the elements of the case are based in Jordan. Therefore, the internationality of the contract is not envisaged unless the dispute is brought before a state other than Jordan (Sadiq: Hisham Ali,1995:71)

In the view of the French jurist, Meyer, who prefers to name the former relationship as foreign, that the mere introduction of this relationship to a foreign country leads to the internationalization of this relationship as a relative rather than absolute international. (Sadiq: Hisham Ali,2007:91)

Based on the above and as a summary of relative internationality, the relationship is an international relation to the personal illusion in two hypotheses:

a. If a contract is concluded between two persons who have the same nationality and live in a foreign country such as two Jordanians living in Italy, the status of the internationality attaches the relationship to the foreign judge from the perspective of the nationality of the contractors, whereas the status of internationality will attach the relationship if presented to the national judiciary because they live abroad.

430 Yustisia Vol. 7 Number 3 (Sept.-Dec. 2018) $\quad$ The Internationalization Of The ... 
b. If all the elements of the legal association are related to a single legal system in terms of place of execution, place of implementation and nationality of the contractors, and the payment is in the same currency and the dispute is presented before a foreign judiciary, the relation will be international (Akasha

Abdel Aal,2007:81).

The international contract is a contract whose elements enter more than one legal system, ie, more than one country. This description is not true in the case of relative internationalism, in which the nodal bond belongs to all its influential elements to one state. But even if the dispute is presented before a foreign judiciary, it is not sufficient to move the rule of conflict, which subjects the contract to the law of will and not according to any system, whether the criterion of focus that defines the applicable law based on the focus of the legal relationship in a specific place or through the will of the parties. (Sadiq: Hisham Ali,2007:91)

Here is an important question arises. Is there a situation in relative internationality that allows the possibility of conflict of laws?

Here, it should be said that not every foreign element in the relationship can confer on it the international character. This type of conflict was called false or unreal. This is what was taken by the American legislator, who stressed that the relationship which is concentrated in one region of the countries and its connection to the jurisdiction of a foreign country does not confer that It has an international character but an element outside the framework of the relationship. This is confirmed by The Hague Convention "Declaration of the parties alone concerning the application of a foreign law or the Covenant jurisdiction to a judge or arbitrator is not enough to give the sale international status (Akasha Abdel Aal,2007:84).

\section{Subjective Internationality}

The relationship is international from a substantive point of view if it communicates through its own elements with two or more states, regardless of the state which may present the dispute before its courts. In equal terms. the attribution of the relationship to two or more states exists in itself and flows from among the internal elements of the relationship before it is brought before any judicial body (Akasha Abdel Aal,2007:80).

The legal relationship, which is characterized by substantive internationalism, as if its own elements were connected to two or more states, regardless of the state in which the dispute was brought before its courts. This relationship is realized, for example, if a resident of Jordan signs a contract with another person in Italy to export goods from Jordan to Italy or vice versa This contract is international 
in itself because it is considered as such whether the dispute is brought before the Jordanian or Italian courts or even the judiciary of other countries (Sadiq: Hisham Ali, 1995:68).

And this is what was taken by Vienna Convention for international sales in Article (1), which determines that to give the international status of the contract where the centers of the work of parties are in different countries, the provisions of this convention are applied to contracts for the sale of goods between parties whose place of business is situated in different States" (The Vienna Convention on International Sales of 1980).

The relationship is international in the substantive sense if we imagine that a Frenchman has concluded a bank loan contract from an English bank located in Cairo and agreed to receive the loan amount from the main branch in London and the money would be invested in Jordan. In such a case, the rules of private international law will move with full force. The contract has the international character, whatever the judicial authority to which the dispute may be raised (Akasha Abdel Aal,2007:80).

Hence, the rule that allows for the movement of rules of conflict must be international and absolutely objective.

We conclude from the above that the work of the rule of conflict which requires the submission of the contract to the law of will requires that we are in the contract of an absolute international character. That is, any contract relates to more than one legal commitment. But if the contract contacts all elements to one country and the dispute is presented before the jurisdiction of foreign country, there is no room for the rule of conflict mentioned before, and the contract is subject to the law to which the legal relationship relates (Sadiq: Hisham Ali, 1995:87).

\section{THE STANDARDS OF THE INTERNATIONALITY OF THE CONTRACT BETWEEN INTERNATIONAL THEORIES AND CONVENTIONS}

The jurisprudence differed on the standard used to define the internationality of a contract as a condition for the operation of the rules of private international law. The traditional jurisprudence has settled on the adoption of the legal standard, which applies to the elements of the nodal association, and the extent to which these characteristics have been addressed by all or some of the elements, while some modern doctrines prefer to focus on the economic criterion, which expresses the extent of association with the interests of international trade (Sadiq: Hisham Ali,2007:71).

432 Yustisia Vol. 7 Number 3 (Sept.-Dec. 2018) $\quad$ The Internationalization Of The ... 
In addition, there is a tendency to combine the two criteria. We will also discuss international standards for international agreements such as The Hague Convention, the Vienna Convention and the Rome Convention.

\section{International Character of the Contract Based on International Standards:}

In this section, we will discuss the legal standard, the economic standard and the mixed or collective standard

\section{a. The Legal Standard}

This trend is based on the basic idea that the contract is considered international if its elements contact more than one legal system. Based on this trend, the contract of sale is considered international if a person residing in Jordan and another person residing in Italy has a contract in Jordan related to the goods in Saudi Arabia and is required to be received in Saudi Arabia, provided that the price is paid in Jordan. Such a contract is international (Sadiq: Hisham Ali,2007:71).

In fact, those who believe in this legal standard have emerged from a fundamental point that the nature of the contract and whether it is international or not is inspired by the legal elements of the union and the extent of its connection to more than one legal system (Akasha Abdel Aal,2007:87).

Despite the agreement of the supporters of this trend on this standard, they disagreed about the effectiveness of the legal elements of the contract and the impact of each in the acquisition of the contract of the international character and some of them said that all the legal elements of the contract have an equal impact. Therefore, if the foreign status is to touch any of them, the contract is characterized as international. While others side said that the acquisition of the contract of international character depends on the nature of the relationship that governs it (Makhlouf: Hanan Abdul Aziz,2010:42). Hence, two criteria which show the strength of the element in characterizing the contract with internationality have been set.

1) The Standard of Equality of Legal Elements:

The international contract is defined according to this standard as a contract that is connected by its elements to more than one legal system. These elements may be objective such as the place of conclusion or the place of execution or personal elements such as home or nationality. This criterion says that the contract is international when any foreign element, whether physical or personal, the elements are equal to each other in terms of strength or effectiveness (Khalid Schuerb,2009:16). This criterion is characterized by stalemate because it leads to the work 
of the rules of international law in any dispute with which an influential or ineffective foreign element is contacted (Sadiq: Hisham Ali,2007:74).

2) Strength Variation Criterion:

This criterion is based on the fact that not every foreign element leads to the internationalization of the contract. Only the positive influencing factor is capable of internationalizing the contract, unlike the non-negative influence which does not lead to internationalization. The contract is not considered international for the mere difference in nationality between the contractors or being incidentally concluded abroad (Akasha Abdel Aal,2007:87).

Hence, it is obvious that there are influential and non-influential elements in the contractual relationship and that the influential elements can only give the contract the international character, the greater the elements of contact are connected with foreign legal commitment, the more influential it will be. It must be said that the element of influence

Is relative, what is influential in a relationship may not be influential in another relationship, since the description of the internationality is achieved only through its connection to other issues which indicate the description of the internationality (Akasha Abdel Aal,2007:89). The definition of international status is related to the issue to be resolved. If a Jordanian bought a US-made car from another Jordanian and a dispute arose over the responsibility of the seller, it is inconceivable to say that the contract is international for being connected to a foreign element (the type of the car), because the nationality of the manufacturer of the car is not important and does not provide the contract with any importance. But if the issue is related to the responsibility of the manufacturing company, represented by American-made car, the foreign element is important in defining the internationality of the contract in contractual relationship (Sadiq: Hisham Ali,2007:78).

Thus, the nationality of foreign contractors is not an influential factor in commercial contracts and contracts in general, because they cannot alone make contracts international (Sadiq: Hisham Ali,2007:75). A contract is not only international because a foreigner endemic in certain country such as Jordan has purchased goods for personal use from the local market. This does not raise the problem of conflict of laws. It is not different in the contract of maritime transport, in which the basis of being international is the difference in the port of navigation and access and the difference of countries, regardless of the nationality of the parties. For example, if an Egyptian person conducted with another Egyptian but residing in Jordan to send goods from the port of

\begin{tabular}{l|ll}
\hline 434 & Yustisia Vol. 7 Number 3 (Sept.-Dec. 2018) $\quad$ The Internationalization Of The ...
\end{tabular} 
Aqaba to the port of Taba. This contract is considered to be international, but if an Egyptian person agrees with another person to transfer the goods from the port of Taba to the port of Alexandria, the contract is not international, even if the nationality of the parties is different (Sadiq: Hisham Ali,2007:76).

The place of conclusion of the contract may be an evidence of an international contract, but at the same time it may be a neutral criterion and is not suitable for the concealment of internationality since it could be merely a coincidence. (Sadiq: Hisham Ali,1995:62) On the contrary, there are legal relations that strongly denote the internationality of the contract as the place of execution of the contract and the difference of the home of the contractors, even if the nationality is united, as called for by the Vienna Convention in article 1/1 (1/3) (Sadiq: Hisham Ali,2007:77). In most assumptions the contract of sale concluded between Jordanians of whom one of them is residing abroad is an international contract. The legal standard has been criticized on the basis that it is not enough to give the international status to some contracts, which do not include any influential element of those of marital status (Makhlouf: Hanan Abdul Aziz,2010:43).

Therefore, the availability of this criterion is done by analyzing the circumstances surrounding the contract to ensure that it is connected to a legal process that necessarily goes beyond the internal rules of one state. However, if the relationship is centered on all its material and moral elements in the framework of legal processes with a purely national class, or one of the parties is a foreigner, or the contract is concluded or carried out abroad coincidentally, the contract cannot be international, because not every foreign element leads to the internationalization of the contract and may be negative and does not affect the nature of the contract. Thus, the circumstances surrounding the nature of the contract are the justifications of the internationality of the contract. But the criterion here is whether the relationship include rules or regulations that are inherently beyond the limits of domestic law. In simple terms, the contract is considered to be international when the contract attachments are connected to more than one state rather than the state of the judge who is in charge of the dispute (Mohammed,2011:15).

\section{b. The Economic Standard}

The modern economic standard emerged in the first third of the 20th century due to the efforts of the French Court of Cassation. It is noted here that the word "International Trade" by the supporters of this phrase takes the broad concept, i.e., it should not be understood in the narrow sense of domestic and civil business. It should include industrial production processes, 
infrastructure construction, technology transfer and pricing contracts. (Mohammad Saad Al-Din,2008:12) The economic standard is adopted to distinguish the international contract. In accordance with this criterion, the contract is international when it relates to the interests of international trade and entails a round-trip movement of goods and services (Akasha Abdel Aal,2007:87). Hence, the economic criterion, when it comes to the interests of international trade, i.e., the contract, which involves attachments that go beyond the internal economy of a given country. It is within the limits of the movement of funds across regional borders back and forth (Mohammed,2011:16).

Thus, the adaptation of the contract as an international or national does not refer to the elements of the contract, but because of the relationship and its link to international treatment in the field of international trade, even if the contract is national in the eyes of the legal standard. In this view, the contract is considered to be an international if it is concluded between a national company and one of the citizen of the same nationality and its goal is to market the company products in a foreign country as the final goal of the contractual process requires the implementation abroad. (Sadiq: Hisham Ali,2007:109). Hence, Thus, the French Court of Cassation, through its various provisions, decided that the international character in this criterion would be first, related to the interests of international trade, ie, which involves a link that transcends the domestic economy of a particular country, including the importation or exportation of goods, and secondly, a round-trip movement of money across borders. (Sadiq: Hisham Ali,2007:105).

The researcher would like to say that the economic criterion does not completely contradict the legal standard under which the contract is related to more than one law. If we analyze the elements in both standards, we will find them similar. We will certainly say that every international contract based on the economic criterion is an international contract based on the legal standard even if the opposite is not always true. If we take an example and analyze its elements, the previous statement is true. If a Jordanian person with another Indonesian nationality are contracted to import goods made in Jordan to Indonesia, we will find that the contract is international in terms of the legal standard, because its connected to more than one legal systems (Jordan and Indonesia). On the other hand, we find that the contract is related to the international commercial interests because it creates the transfer of goods and money beyond borders.

We conclude from this that the availability of the economic standard of the international contract necessarily leads to the acquisition of contractual

436 Yustisia Vol. 7 Number 3 (Sept.-Dec. 2018) The Internationalization Of The ... 
attachments of its international character in accordance with the legal standard, even if the opposite is not true as the contract may acquire international status in accordance with the broad legal standard without achieving the economic criterion of this state. This occurs in all hypotheses in which the foreign attribute is referred to as an ineffective element in the contractual attachments, as it is related to the nationality element in financial transactions (Sadiq: Hisham Ali,2007:111).

Many criticisms have been made against this standard, including: This criterion is criticized for being vague and undefined. It does not add any new. It is merely an application of the legal standard, and its supporters differed on the scope of its application (Makhlouf: Hanan Abdul Aziz,2010:43). On economic contracts, Boutefl said that the economic standard does not fit with the expansion of new classes of contracts and is not fit to address them and determine the scope of their application. only the legal standard can do this. Also the jurist (Lovssovarn), who determines that the rigid legal standard is better than the variable economic standard (Mohammed,2011:17).

\section{c. The Mixed Standard.}

In view of the above, and after presenting the theories that give the contract international status, we find that the legal criterion can be taken when the relationship is related to more than one legal system. On other times, the economic criterion is adopted when the relationship is related to the interests of international trade, this led to a trend that saw the combination of the legal and economic standard so that the contract is not internationally accepted unless it combines the elements of the two standards. (Khalid Schuerb,2009:21)

In applying this standard, the contract is characterized by internationality only if it meets international standards in accordance with the requirements of both criteria. It should be connected to the interests of its international trade and is connected to more than one legal system. (Mohammed,2011:18).

However, reliance on the idea of applying the mixed standard is subject to some limitations, in terms of determining the influential element in the legal relationship and in terms of applying the international legal standard of contract and defining the concept of international trade in an expanded manner. (Mohammed,2011:18).

In the researcher simple point of view, the previous criticism is not consistent with the adaptation of the legal relationship as international or not, because the description of internationality can only be revealed through a set of conditions surrounding the contract itself. The contract cannot be 
described as international unless the circumstances surrounding it as the place of the contract implementation or conclusion show that it is international. This is what Dr. Akash Abd-Alal has said. He said that the description of Internationality cannot be found by itself or by an abstract or absolute manner, but through specific matters which shows its internationality.

\section{The International Character of the Contract Based on International Conventions.}

The international conventions differed in the application of international standards of the contract. Some adopt the legal standard, while others prefer the combination of the legal standard and the economic one. These conventions are:

a. The European Convention on International Commercial Arbitration in 1961: The

European Convention on International Commercial Arbitration, concluded in 1961 has adopted the mixed standard. Its first article says: "The provisions of this Convention shall apply to arbitration agreements concluded with a view to resolving disputes arising or may arise as a result of international trade transactions between private or legal persons and shall have at the time of the establishment of the agreement a habitual residence or a duty station in different States which are contractually bound by this Convention." (European Convention on International Commercial Arbitration, article 1 (1961)

b. The Hague Convention on the Law Applicable in International Sale in 1986

"The sale of movables is international when the business center of the parties to the contract are in two different countries and the status of the parties to the contract are in two different countries when the goods are transferable from one country to another." (Hague Convention on the Law Applicable in the Scope of International Sale). The standard introduced by the Uniform Law for International Sale established under The Hague Convention in 1986, international sale in accordance with this standard is not related to the nationality of the contractors as the sale may be considered international even if both the seller and the purchaser are of a single nationality. What is important is the difference between the business centers of the contracting parties or their habitual residence (Al-Sharqawi: Mahmoud Samir,1992:16). The Hague Convention did not take into account the relative internationality, therefore, it says: "Declaration of the parties on the application of foreign law alone or the covenant of jurisdiction of a judge or arbitrator is not sufficient to give the sale an international character. (Hague Convention on the Law Applicable in the Scope of International Sale). 
c. Vienna Convention on International Sales of 1980

This Convention adopted the centers of business of the two parties to be in different countries according to Article (1) The jurisprudence differed about the intended meaning of the center of business. Some of them said it is meant to be the main center of the company or a person that is stable, and others said that it is possible to be part of his activity provided that it enjoys stability (Makhlouf: Hanan Abdul Aziz,2010:43).

The Convention has chosen one personal standard in its text (1/1), that is, the Convention shall be applied to the contract of sale concluded between parties whose facilities are located in different countries (Mousa Talib Hassan,2008:158)

$(1 / 3)$ "The nationality of the parties and the civil or commercial character of the parties or the contract shall not be taken into account in determining the application of this Convention." (United Nations Convention on International Goods (Vienna) 1980).

It is clear that the Vienna agreement has taken the legal criterion to determine the international status of the contract because it required the connection of the relationship with more than one legal system and ignored the economic standard that arranges the movement of goods. (Makhlouf: Hanan Abdul Aziz,2010:43).

In my simple point of view, as a researcher, I don't agree with the previous

opinion that Vienna Convention did not take the economic standard into account, even if not directly authorized it, but mentions it specifically in Article

2 , which mentions that a person buys goods even from abroad, but because of personal use, removes from the contract the international status even if the parties differ in the place of residence. This indicates the existence of the economic standard in the Vienna Convention. The provisions of this Agreement shall not applied to the following sales:

(A) Goods purchased for personal, household or domestic use.

d. Rome Convention of 1980 on the law applicable to contractual obligations.

The Rome Convention of 1980 on the Law Applicable to Contractual Obligations states in the first paragraph of Article (1) that "treaties shall be applied to centers of conflict of laws in respect of contractual obligations."

This may indicate that the rule of attribution established in Article (3/1), which subjects the law chosen by the parties to the contractual ties of an international character. However, paragraph (3/3) it states that the selection of contractors to a foreign law does not result if all elements of the contract are concentrated in one state at the time of choice, to prejudice the texts of 
the matter prescribed in the law of the state, and individuals cannot agree to oppose them (Sadiq: Hisham Ali,1995:55).

The Rome Convention did not depart from what is familiar in this sense, but it allowed the contractors to choose the law applicable to the contractual set, in which all elements belong to one country, provided that the rules of the matter are not affected by the law of the state to which that set belongs. (Sadiq: Hisham Ali,2007:66).

Finally, such a combination of the legal standard and the economic standard adopted by most international conventions will lead to the same result that can be realized if the judiciary is limited to the narrow legal standard, which does not take into account its influential elements without neutrality. In fact, the adoption of the economic criterion and the legal one will lead to the non-appreciation of the foreign element that the contractual relationship contains unless it is influential. The foreign element can be influential in the field of international transaction contracts if it leads to the transfer of funds or services across the border, in other words, if the contracts exceeded the framework of the internal economy (Sadiq: Hisham Ali,1995:72).

\section{CLOSING}

\section{Conclusion}

From the above discussion, the conclusion can be taken as follows:

To activate the rule of conflict, which requires the submission of the contract to the law of will requires that we are in a contract of an absolute international character, that is, the contract that is related to more than one legal system. This cannot be true in absolute relativity. Therefore, if the contract is connected in all its elements to one country and the dispute is presented to the jurisdiction of foreign country, there is no room for action on the basis of the conflict mentioned above. Here, the contract is subject to the law in which the legal relationship is related. Hence, the circumstances surrounding the nature of the contract are the justifications of the international contract and not only the will of the parties and the influential elements which can give the contract international character.

The availability of the economic standard of the international contract necessarily leads to the acquisition of the contractual relationship of its international character in accordance with the legal standard, even if the opposite is not true as the contract may acquire international status in accordance with the broad legal standard without achieving the economic criterion of this state and this occurs in all the hypotheses, in which the foreign status is related to an

440 Yustisia Vol. 7 Number 3 (Sept.-Dec. 2018) $\quad$ The Internationalization Of The ... 
ineffective element In the contractual relationship, as the case of the nationality element in financial transactions.

The combination of the legal standard and the economic criterion will lead to the same result that can be realized if the judiciary is limited to the narrow legal standard, which is only valid for the neutral influential elements. in fact, the adoption of the economic criterion along with the legal standard will lead to nondependence on the foreign element contained in the contractual relationship unless it is influential. The foreign element can be influential in the field of international trade if it leads to the transfer of funds or services across borders, i.e., if these contracts exceed the framework of the internal economy.

\section{Suggestion}

a. The adoption of the narrow legal standard in determining the international status of the contract helps to determine the international character precisely because it works to select the influential elements in the relationship and identify the strong elements.

b. Limiting the relative internationality in personal relations disputes and not applying it on commercial contracts, because it cancels the difference between international and internal contracts.

c. The judge is responsible for adapting the relationship and giving the description of the internationality, therefore he should realize the internationality of the contract from physical matters presented to him without following the previous judicial cases because the element that may be influential in a conflict may not be influential in another dispute even if the same element based on the relative foreign character of the contract.

\section{BIBLIOGRAPHY:}

\section{Books:}

Abdel-Al: Akasha Mohamed, 2007, International Banking Operations Law, New University House: Egypt.

Makhlouf: Hanan Abdul Aziz, 2010, International Contracts, Faculty of Law, Banha University: Egypt.

Mousa: Talib Hassan, 2008, International Trade Law, Dar Al Thaqafa for Publishing and Distribution 1: Amman.

Sadiq: Hisham Ali, 1995, The Law Applicable to International Trade Contracts, Knowledge Establishment: Egypt. 
Sherkaoui, Mahmoud Samir, 1992, Special Study for the Contract of the International Sale of Goods, Dar Al Nahdah Arab: Egypt.

Sadiq: Hisham Ali, 2007, International Trade Contracts, University Press House: Egypt.

\section{Researches:}

Mohammad: Saad Al-Din, 2008, International Contract between Emiratization and Internationalization, Master's Thesis, Faculty of Legal and Administrative Sciences, Hassiba Bin Ali University: Algeria

Mohammed, 2011, Rules of Conflict and Physical Rules in Disputes, International Trade Contracts, Master Thesis, Faculty of Law and Political Science, University of Abu Bakr Belqayd, Algeria.

Shuwairb, Khalid, 2009, The Law Applicable to the International Commercial Contract, Doctoral Thesis, Faculty of Law, University of Algiers.

\section{International Laws and Conventions:}

Jordanian Civil Law No. 43 of 1976

Rome Convention of 1980 on the law applicable to contractual obligations

Vienna Convention on International Sales of 1980

The Hague Convention on the Law Applicable in International Sale in 1986

The European Convention on International Commercial Arbitration, concluded in 1961

Law Number 15 of 2015 on The Jordanian Electronic Transactions Law

442 Yustisia Vol. 7 Number 3 (Sept.-Dec. 2018) The Internationalization Of The ... 